\title{
Coexisting with wildlife in Transfrontier Conservation Areas in Zimbabwe: cattle owners' awareness of disease risks and perceptions of the role played by wildlife
}
M. de Garine-Wichatitsky ${ }^{1,2^{*}}$,
E. Miguel $^{1,2,3}$,
B. Mukamuri ${ }^{4}$, E. Garine-

Wichatitsky $^{5}$, J. Wencelius ${ }^{5}$, D. M. Pfukenyi ${ }^{6}$, A. Caron ${ }^{1,2,7}$

${ }^{1}$ Cirad-Zimbabwe, Harare, Zimbabwe

${ }^{2}$ Cirad, Montpellier, France

${ }^{3}$ CNRS, Université Lyon I, Lyon, France

${ }^{4}$ Centre for Applied Social Sciences, University of Zimbabwe, Harare, Zimbabwe

${ }^{5}$ Université de Nanterre, Nanterre, France

${ }^{6}$ Veterinary Faculty, University of Zimbabwe, Harare, Zimbabwe

${ }^{7}$ Mammal Research Institute, University of Pretoria, Pretoria, South Africa

*Corresponding author: degarine@ cirad.fr

\begin{abstract}
Diseases transmitted between wildlife and livestock may have significant impacts on local farmers' health, livestock health and productivity, overall national economies, and conservation initiatives, such as Transfrontier Conservation Areas in Southern Africa. However, little is known on local farmers' awareness of the potential risks, and how they perceive the role played by wildlife in the epidemiology of these diseases.
\end{abstract}

We investigated the knowledge base regarding livestock diseases of local cattle owners living at the periphery of conservation areas within the Great Limpopo TFCA and the Kavango-Zambezi TFCA in Zimbabwe, using free-listing and semi-structured questionnaires during dipping sessions. The results suggest that information related to cattle diseases circulates widely between cattle farmers, including 
between different socio-cultural groups, using English and vernacular languages. Most respondents had an accurate perception of the epidemiology of diseases affecting their livestock, and their perception of the potential role played by wildlife species was usually in agreement with current state of veterinary knowledge. However, we found significant variations in the ranking of livestock diseases between sites, and owners' perceptions were not directly related with the local abundance of wildlife. In contrast, awareness of zoonotic risks and of the potential increase in TADs with the establishment of TFCAs, seemed low. We recommend the establishment of a One health program, including information and awareness on zoonotic diseases, with increased participation of communities at a local level in the prioritization of disease control and surveillance.

Keywords: veterinary epidemiology, perception, wildlife/livestock interface, diseases, TFCA 


\section{Introduction}

Domestic and wild animals are coming into ever-more intimate contact in many interface areas throughout the world, leading to human-wildlife conflict. Hence finding solutions to improve co-existence of wildlife with cattle emerges as a key issue for the development of rural communities and for biodiversity conservation [1]. Among various types of humanwildlife conflicts [2], disease transmission is one of the major negative consequences suffered by people, and their livestock, living at human/wildlife/livestock interfaces [3], and many low-income countries cannot respond adequately to emerging zoonotic diseases that affect humans as well as animals [4].

Diseases associated with wildlife may negatively affect local farmers in several ways. First, the health status of livestock owners and their families may be directly affected, as a number of zoonotic pathogens have been isolated from wild species [5]. Indeed, wildlife has been confirmed as a source of major emerging diseases such as Highly Pathogenic H5N1 or SARS that have resulted in pandemics during the last decades $[6,7]$. Human populations living at the periphery of conservation areas in tropical regions, which are considered as "hotspot areas" for potential future emergence [8], are thus particularly at risk of being infected by emerging pathogens. Second, wildlife-related diseases may cause direct mortality or reduce productivity of livestock and they are also indirectly responsible for reduced marketing opportunities. Current international rules, as compiled by the OIE in Terrestrial Animal Health Code [9], regulate the trade of animals and animal products in order to prevent the spread of Transboundary Animal Diseases (TADs) between countries. Wildlife species have been demonstrated to act as reservoirs of several important TADs, such as the African buffalo acting as a natural reservoir of foot and mouth disease $[10,11]$. As a consequence, livestock living adjacent to areas where these wild hosts roam cannot be freely moved and marketed outside their area of origin. Third, livestock is of considerable socio-cultural importance for many agro-pastoral communities living at the periphery of conservation areas, and wildlife-borne diseases may therefore threaten their livelihoods. 
In the context of the developments of Transfrontier Conservation Areas (TFCAs), involving most countries in Southern Africa, disease transmission at the wildlife-livestock interface has been identified as a major challenge $[3,12]$. TFCAs have been promoted throughout the region as a way to reconcile conservation and development objectives, simultaneously contributing to global biodiversity conservation, regional peace and the sustainable socio-economic development of African communities, through increased crossborder collaboration and ecotourism. However, the expected increase of movements of people and animals across the boundaries of "re-connected" conservation areas presents new challenges for both public and animal health [13]. With the growing recognition of the critical role of animal health in tropical regions, mitigation of disease transmission at the human/wildlife/livestock interface has thus become a major development and conservation issue $[12,14]$.

Cattle-owners play a critical role in the implementation of veterinary disease control programmes. However, although TADs do have negative impacts at local as well as national levels in developing countries, priorities and strategies for disease control are always dictated at national and international levels, with little attention paid to the views and opinions expressed at grass-root level by cattle keepers. To that extent, community-based animal health delivery services have been promoted for the past two decades in Africa [15], in an attempt to better address priorities of local cattle owners. Participatory epidemiology has also been developed as a way to improve the involvement of animal keepers in animal disease control programmes and policies, including prioritization of diseases [16].

The success of veterinary disease control measures largely depends on the knowledge base of cattle owners with regard to diseases [17], and farmers are demanding a greater involvement in the effective management of wildlife-associated diseases that do affect them and their livestock [18]. However, little is known on local farmers' awareness of the potential 
risks, and how they perceive the role played by wildlife in the epidemiology of these diseases. The knowledge bases and the perceptions of wildlife-associated diseases by southern African livestock keepers living at the periphery of conservation are likely to be heterogeneous for several reasons. First, the mechanisms involved in the epidemiology of infectious diseases are very complex [19], especially when they involve wild host reservoirs, and there are several diseases for which the role of wildlife is still open to question among wildlife epidemiologists [20]. Second, people living at the periphery of conservation areas in southern Africa are often of different ethnic origins [21], and they settled in these areas for variable periods of time, often after being displaced from their area of origin following events that may not be directly related to the existence of the conservation area $[22,23]$. As the cultural background of people influences their representations of illness and diseases [24], it is likely that cattle-keepers living at wildlife-livestock interfaces in southern Africa have different cultural views about the importance and epidemiology of livestock diseases. It is also possible that the knowledge related to wildlife depends on the time of residence in a given ecological context, and thus recent migrants may have different perceptions of the role played by wildlife in the epidemiology of livestock diseases. Alternatively, livestock diseases might be a topic for which there is a general consensus, as a result of intense intercultural exchanges promoted by shared veterinary facilities (such as dip-tanks) and gatherings of livestock keepers and their cattle at cattle markets.

The current study investigates the knowledge of local cattle owners with regard to diseases affecting their livestock and how they perceive the role played by wildlife species in the epidemiology of these diseases in contexts of high or low abundances of wildlife in Zimbabwe. 


\section{Material and methods}

\section{Study area}

All questionnaires were implemented in communal lands adjacent to conservation areas in Zimbabwe (Figure 1). Two areas were investigated: 1) The South East Lowveld (SEL) of Zimbabwe is a semi-arid ecosystem with less than $600 \mathrm{~mm}$ of rainfall per year on average. Part of the SEL is included in the Great Limpopo TFCA (GLTFCA), encompassing national parks, private conservancies and communal lands in Mozambique, South Africa and Zimbabwe. The study areas were located in Zimbabwe, at the periphery of Gonarezhou National Park (GNP) and Kruger NP (KNP) in South Africa; 2) The periphery of Hwange National Park (HNP) in the Matabeleland North Province of Zimbabwe. This area is also a semi-arid area with on average 1000mm rainfall per year. HNP and its periphery are included in the newly created (2011) Kavango-Zambezi (KAZA) TFCA, between Angola, Botswana, Namibia, Zambia and Zimbabwe.

GNP, HNP and some areas of KNP are characterised by soft boundaries (i.e. no physical barrier separating the protected area from the adjacent communal land). Veterinary fences erected along some sections of these national parks for foot and mouth disease control used to prevent contacts between buffalo and cattle. However, due to a lack of maintenance following the economic downturn in Zimbabwe since the early 2000s, these fences have been extensively damaged by wildlife and humans' challenges and they are currently permeable to animal movements both ways.

Dip-tanks were selected in the periphery of GNP and HNP in a buffer of up to $35 \mathrm{kms}$ around protected areas boundaries (i.e. national parks, safari areas, hunting areas, conservancies and forestry commission lands, adjacent to national park). In Zimbabwe, animal health regulations compel cattle owners in communal lands to dip their cattle weekly during the rainy 
season and fortnightly during the dry season for control of ticks and tick-borne diseases. Considering that over $90 \%$ of cattle owners dip their cattle (DVS Reports), dipping attendance was believed not to be a significant source of selection bias for the farmers. Hence, due to easy access to cattle owners during the dipping sessions, dip tanks were selected as the study sites for interviews with cattle owners. The selected areas (Figure 1) included a total of 24 dip-tanks located in the SEL (Chanyenga, Chigweziwa, Chikhovo, Chikombedzi, Chishinya, Chitsa, Chizvirizvi, Chomupani, Davata, Faversham, Gurungweni, Makambi, Malipati, Maose, Matihwa, Muhlekwani, Nyabongwe, Nyangambe, Pahlela, Pesvi, Pfumare, Piri, Rupangwana, Tsovani) and 5 dip-tanks in the Hwange area (Kamativi, Chezhou, Sialwindi, Mabale and Lupote).

\section{Interviews at various wildlife/livestock interfaces}

Questionnaires were administered by previously trained staff of governmental veterinary services $(n=22)$ to randomly selected volunteer participants during dipping sessions. The survey was conducted between February 2008 and December 2009 in the SEL, and in March 2010 in the Hwange area. The interviews were carried out individually, each cattle keeper being interviewed by the veterinary technician attached to his dip-tank, a familiar person often residing within the community.

The interviews were organised in three sections: 1) general information regarding the informant socio-economic status: main (and secondary) occupation, household composition, socio-cultural background (ethno-linguistic group, time of residence in the area), species and numbers of livestock owned; 2) "free-listing" of names of livestock diseases known by the informant. This was done through a preamble which explained the procedure and clearly indicated that names could be given in any language (including local vernacular names), the informant was then invited to list all the names of livestock diseases known to him, the enumerator being in charge of the transcription of the names given orally (to avoid possible bias against illiterate respondents); 3) disease symptoms and role of wildlife: for each name of disease listed, the informant was 
invited to detail the symptoms of the disease, indicate if wildlife was associated with the disease (Yes/No/Don't know), and if "Yes" list the main wildlife species involved and how they are involved in the epidemiology of the disease in livestock.

Group discussions were also carried out with four dip-tank committees (Malipati, Pfumare, Pesvi, Pahlela) several months after the completion of the survey. The discussions were aimed at presenting and discussing preliminary results on disease ranking and perceptions on the role of wildlife in the epidemiology of the diseases.

\section{Data analysis}

The disease names were given by the informants in vernacular languages (Nambya, Ndebele, Shangani, Shona; no distinction was made between the Shona dialects, Karanga, Korekore, Manyika, Ndau and Zezuru) and in English. The original lists of vernacular names (after normalising the spelling of the names) and the list of deduced diagnoses (putative diseases or syndromes deduced by veterinarians from the symptoms and aetiology as described by the informant) were analysed separately. For each list, we analysed the length of the list (total number of names given) and the position of the elements of the list (average rank of citation of each disease name; low rank indicates that the item was cited early in the list, e.g., $1^{\text {st }}$ or $2^{\text {nd }}$ ) according to the local abundance of wildlife, the socio-cultural origin and the time of residence of the cattle owner in the area.

Three sources of information regarding contacts between wildlife and livestock were used to build a composite variable of wildlife abundance, "Composite wildlife abundance": 1) Perception of veterinary livestock technicians based in the area, categorised in 0,1 and 2 respectively for no, moderate and high occurrence of wildlife in the area; 2) The shortest distance between the GPS position of the area and the closest protected area with known presence of wildlife; 3) Expert knowledge by key informants (wildlife managers or 
researchers). The final "Composite wildlife abundance" variable was categorised as 0 (no wildlife/livestock contact), 1 (rare wildlife/livestock contacts due to low wildlife densities or to the presence of well maintained ungulate proof fences) and 2 (medium to high density of wildlife and absence of barrier preventing contacts). This variable is significantly correlated to the distance to the nearest protected area (Spearman Rank Correlation test, $r=-0.87$, $\mathrm{p}<0.001)$.

Each respondent was allocated to one of the major ethno-linguistic groups ("Ethnic origin": Nambya, Ndebele, Shangani, Shona or Tonga) according to the language he used for the list of disease names and the information given on his mother language. A synthetic variable with 4 classes indicating the "history in the area" of the informants was created, including information on time of residence in the area and place of birth of parents and grandparents. In summary, the following socio-economic data of the informant was collected: local resident (parents and grandparents borne in the area), old migrant (parents borne in the area), middle range migrant (parents not borne in the area, but informant resides for $>20$ years in the area), recent migrant (immigration $<20$ years).

Non-parametric analysis of variance (Kruskal-Wallis test) was used to compare the number of diseases listed by informants in relation to the "Composite wildlife abundance" , "ethnic origin" and "history in the area" variables. Chi-square tests were used to compare proportions of answers (e.g. "Is this disease related to wildlife?") or proportions of answers in agreement with available veterinary knowledge for different values of "Composite wildlife abundance", "history in the area" and "ethnic origin". All statistical analyses were performed using R software [25]. 


\section{Results}

A total of 254 individual questionnaires were administered between February 2008 and December 2009 in the SEL $(n=218)$, and in March 2010 in the Hwange area $(n=36)$. All respondents were directly involved in livestock keeping (7 did not answer that question), with the majority of them mentioning farming as their only professional activity $(n=132)$ or some involvement with agriculture extension services $(n=94)$, while less than $10 \%$ indicated that they had another significant activity $(n=21)$. Using the "Free-listing" questionnaire, a total of 1059 different names of livestock diseases were collated from the 254 respondents. $49.6 \%$ of the respondents acknowledged Shangani as their mother language but only $2.8 \%$ of the disease names were given in Shangani, whereas $20.1 \%$ named Shona as their mother language, and $21.6 \%$ of the disease names were given in this language. Ndebele speaking people represented $9.4 \%$ of the farmers interviewed, and $2.4 \%$ of diseases names were given in this language, whereas $72.4 \%$ of the disease names were given in English. The remaining minority languages mentioned by the respondents as their mother tongue represented less than $6 \%$ of the sample (Nambya, 5.9\%; Tonga, 1.9\%; other minorities 2.0; no response, $11.4 \%$ ), and no disease name was given in these languages (except for 1 name in Nambya). The full list of names given in English and in vernacular languages is given as supplementary material (Table S1), along with the most frequently associated putative disease (or syndrome), as identified by veterinarians based on the symptoms described by the respondents and the knowledge of livestock diseases prevailing in the areas (e.g. [14, 26, 27]).

The most frequently cited vernacular name for a given disease/syndrome was usually the same for the majority of respondents, regardless of their ethno-linguistic group (Table 1). "Foot and mouth" disease for instance, was the most frequently and early mentioned term by cattle owners of all ethnic groups (Table 1) with the majority of Ndebele (65\%), Shona (52\%), Shangani $(63 \%)$ and other minority groups $(55 \%)$ using the English name. However, there 
was also evidence that shared intercultural semantic domain regarding cattle diseases involved the use of other vernacular languages. For instance, a Shona name referring to foot and mouth disease ('Chamahwanda') was mentioned by $17 \%$ of the Shona respondents, and also by $8 \%$ of the Shangani and $3 \%$ of the Ndebele (Table 1). Similarly, the English word 'Lumpy skin' (also spelled 'Lumpskin') was the most frequently mentioned for lumpy skin disease (LSD), used by $27-37 \%$ of Ndebele/Shona/Shangani/Other language (Table 1); but a Shona word ('Chamapundu') referring to the same disease was used by $19 \%$ of Shona respondents, $11 \%$ of Shangani and 6\% of Ndebele (Table 1), and the Shangani spelling ('Chamabhunzu') was also used by $3 \%$ of the Shangani respondents $(n<5$, result not shown in Table 1$)$. As a last example, the Ndebele term 'Isikwekwe', which seems to refer to dermatophilosis according to the symptoms described by the cattle keepers interviewed, was mentioned by $19 \%$ of the Ndebele and $18 \%$ of the other minorities (mostly Nambya in this case), whereas the English word 'Dermatophilosis' was only used once, and no other name was used to refer to this disease, which is apparently only encountered in the western part of Zimbabwe.

The number of diseases listed by the respondents ranged $1-9$, with only $8.3 \%$ of the respondents listing more than 7 names. The length of the lists did not differ significantly between ethnic groups of farmers $(\mathrm{n}=246, \mathrm{~K}=1.5, \mathrm{df}=3, \mathrm{p}=0.681)$. However, the length of the lists differed significantly according to: 1) the "Composite wildlife abundance" variable $(\mathrm{n}=254, \mathrm{~K}=34.7, \mathrm{df}=2, \mathrm{p}<0.001)$ with longer lists given in areas where wildlife abundance ("Composite wildlife abundance" variable) was lower; 2) the "history in the area" of interviewees $(\mathrm{n}=235, \mathrm{~K}=9.5, \mathrm{df}=3, \mathrm{p}=0.024)$, with medium and recent migrant giving on average longer lists than old migrant and local farmers.

The ranking of diseases and syndromes identified from the list of names given by the cattle owners interviewed varied between localities. Table 2 indicates the average ranking of the most frequently cited diseases by interviewees attached to groups of dip-tanks defined 
according to their geographic proximity and the local relative abundance of wildlife (see definition of 'Composite wildlife abundance'). Foot and mouth disease was the exception, as it was consistently mentioned with the lowest rank $\left(1^{\text {st }}\right.$ or $\left.2^{\text {nd }}\right)$ by cattle owners from all 12 dip-tank groups. But the ranking of the disease listed after FMD was variable between groups of dip-tanks. There was some consensus regarding LSD, Blackleg and Heartwater, usually ranked $2^{\text {nd }}, 3^{\text {rd }}$ and $4^{\text {th }}$, respectively, although some discrepancies were apparent between groups of dip-tanks (e.g. Blackleg ranking [1-5]). For most other diseases, however, large variations in ranking were apparent between dip-tank groups, with some disease ranks ranging enormously: e.g. [2-7] for Anthrax, [4-12] for Foot rot and [1-11] for Babesiosis. Some diseases were only mentioned from a few dip-tank groups, such as Theileriosis (mentioned at 4 DT) or Dermatophilosis, which was only mentioned at the group of DT located at the periphery of Hwange, with a low rank $\left(3^{\text {rd }}\right)$.

Out of 55 diseases and syndromes identified, $29.1 \%$ are known to be related to wildlife, $29.1 \%$ are not known to be related to wildlife and for $41.8 \%$ of them (including the 20 syndromes) no available knowledge exists on the role of wildlife (Table 3). Interviewees cited diseases or syndromes known to be related to wildlife in $61.9 \%$ of cases, diseases or syndromes not known to be related to wildlife in $18.1 \%$ of citations and diseases or syndromes with a lack of knowledge in $20.0 \%$ of cases.

Overall, $36.6 \%$ of the respondents perceived that wildlife was involved in the transmission of diseases listed, but $24.8 \%$ said that wildlife did not play any role $(38.5 \%$ did not know or did not respond to the question). These proportions were not significantly different for each value of the "Composite wildlife abundance" variable $\left(\mathrm{n}=1059, \mathrm{Khi}^{2}=6.9\right.$, $\mathrm{df}=4, \mathrm{p}=0.139)$. The proportion of farmers' perceptions in agreement with available veterinary knowledge about the role of wildlife in the epidemiology of livestock diseases listed did not differ according to "history in the area" $\left(\mathrm{n}=974, \mathrm{Khi}^{2}=0.8, \mathrm{df}=4, \mathrm{p}=0.933\right)$ 
and "Composite wildlife abundance" in the area $\left(\mathrm{n}=974, \mathrm{Khi}^{2}=1.2, \mathrm{df}=2, \mathrm{p}=0.538\right)$. However when considering the most cited disease (Table 4), different patterns were observed: 1) Farmers in strong agreement with current epidemiological knowledge (e.g. foot and mouth disease, rabies); 2) Farmers unaware of the role of wildlife in the epidemiology of the disease (e.g. brucellosis, Newcastle disease); 3) As current knowledge about the role of wildlife in the epidemiology of the disease is not clear (i.e. the disease has been directly or indirectly identified in wildlife species but the transmission between wildlife and domestic species has not yet been proven), farmers' answers is close to random selection (between 3 options, "Yes", "No" and "Don't know") (e.g. tick-borne diseases, such as heartwater, babesiosis, anaplasmosis, or anthrax).

\section{Discussion}

The knowledge base related to livestock diseases of cattle keepers living in TFCAs in Zimbabwe was relatively homogenous between respondents from various localities. As for many semantic domains related to the environment or to technical issues, few 'specialists' held most of the knowledge (longer lists of disease names given) at each dip-tank surveyed, although this was not very apparent as the maximum number of disease names given was relatively small. These 'specialists' may have been people associated in some ways with the veterinary or agricultural extension services (dip-tank attendant, member of the dip-tank committee, Agritex staff), with a relatively high level of education which allowed them to name diseases in English. Although the questionnaire procedure adopted was meant to emphasize the fact that names given in any vernacular languages could be included in the list, our results may have been biased towards English and Shona languages. The enumerators trained to administer the questionnaire were all veterinary and livestock technicians attached to the Animal Health Centre servicing the dip-tanks surveyed and, although most of them had lived within the communities for months or years, the majority of them were Shona people 
originating from other parts of the country. Despite this possible language bias, we found evidence of extensive intercultural exchanges of information related to livestock diseases between cattle keepers. Most of the disease names were given in English, which might be related to the fact that veterinary and agricultural extension officers in Zimbabwe are trained in English; but many names were also given in Shona, Ndebele or Shangani by livestock keepers from different socio-cultural groups. In fact, belonging to a given ethno-linguistic group, or being a migrant $v s$. local farmer, did not seem to influence the knowledge base or the ranking of livestock diseases by cattle keepers living in TFCAs in Zimbabwe, which does not seem to indicate the importance of a "cultural epidemiology" [24] in this case.

We found however great variations in the local perception of priority diseases among cattle keepers attached to different dip-tanks, as indicated by the variations in disease ranking. Foot and mouth disease was an exception, as it was systematically cited by cattle owners on top of the list at all dip-tanks. This can be explained by the important and constant actions carried out by the veterinary services of Zimbabwe during the past decades in an attempt to control FMD at the periphery of conservation areas in order to export beef from FMD-free areas of the country to the lucrative European Union market (e.g.[28]). The high and consistent ranking of this disease probably does not reflect the importance of its direct impact, as FMD has minor direct impacts and seldom results in mortality of infected cattle compared to other diseases. But it shows the importance of the indirect consequences of the control measures put in place, which have direct consequences on cattle owners, including compulsory vaccination, restriction of the movements of cattle outside the area and the erection of FMD-fences to prevent contact of cattle with buffalos. Apart from FMD, the perceptions of livestock diseases priority varied greatly between dip-tanks. This result has some important consequences for the strategies of disease control. In some cases, the priority given to a disease may be justified by explicit reasons, such as the buffalo-derived theileriosis 
that was most frequently mentioned by cattle keepers living close to conservation areas with permeable fences, or dermatophilosis that was only mentioned by farmers living in KAZATFCA, as the disease has apparently not spread to the GLTFCA area in Zimbabwe. In other situations, the consensual priority diseases or syndromes that have emerged at dip-tank level among cattle keepers might not be explicitly justified or might not correspond to the priorities of the national veterinary services or wildlife managers. These priorities should be assessed at local (dip-tank) level and taken into account when designing and implementing livestock disease control operations, and participatory epidemiology may provide the appropriate methods to ensure the involvement of local communities in the prioritization exercise [16].

Perceptions of livestock keepers on the epidemiological role of wildlife in livestock diseases usually corresponded to the "state of the art" in veterinary wildlife epidemiology. For some diseases such as foot and mouth disease and rabies, the involvement of wild reservoirs (African buffalo Syncerus caffer and wild carnivores respectively) in the epidemiology of the disease was usually well known and explained to the enumerators. Buffalo was mentioned as the main wildlife reservoir for almost all the cattle diseases or syndromes listed and, although this statement does not always agree with current scientific evidence, veterinarians have often come to the same conclusions after investigating the epidemiological role of buffalo, "the usual suspect" [29]. Other wildlife species, such as elephant Loxodonta africana, Cape eland Taurotragus oryx, civet cat Civettictis civetta, and ground hornbill Bucorvus leadbeteri may have been mentioned in relation to their symbolic and cultural values, as their putative role as wildlife reservoirs of cattle disease is not backed by current scientific evidence.

Discrepancies between local farmers and veterinary experts opinions regarding the epidemiological role of wildlife were often associated with diseases for which there is only incomplete scientific knowledge (e.g. lumpy skin disease), or for which the role played by wildlife has been only recently confirmed (e.g. brucellosis), or with diseases which have 
complex mechanisms of disease transmission that do not necessarily involve wildlife (e.g. ticks and tick-borne diseases). During a survey on cattle owner's awareness of BTB in Zambia, Munyeme et al [30] found that the level of awareness of the disease among farmers was higher in areas where the prevalence was high. Similarly, we expected that knowledge of the epidemiological role of wildlife in cattle disease would be higher in areas with higher occurrence of wildlife, but this was not the case. The fact that there was no significant variation in knowledge and perception on the role of wildlife between famers living with locally abundant wildlife/no wildlife, or between recent migrants/local farmers is noteworthy. First, this shows that information regarding livestock health, an important issue indeed for cattle keepers in the GL-TFCA and KAZA-TFCA, is circulating fast and efficiently, within and between groups of farmers associated at dip-tank level. This possibly happens through discussions at cattle markets (which gather farmers from several dip-tanks) and also possibly reflect the efficiency of the veterinary extension network which are present even in remote areas. Second, contrary to other types of human-wildlife conflicts (e.g. predation on livestock by wild carnivores; [2]), it seems that cattle farmers living closer to conservation areas do not perceive an increased disease burden on their cattle due to the close proximity of wildlife. The current attitudes of cattle owners living in the GL-TFCA and the KAZA-TFCA towards wildlife conservation initiatives are not negatively affected by a perceived increased risk of disease transmission to cattle. However, awareness of people regarding TFCAs initiatives, which were seldom mentioned spontaneously by the people on the ground, is still very low, especially the concern about a possible increase in disease spread with increased animal movements $[13,31]$, and the recent emergence of bovine tuberculosis from South Africa to Zimbabwe [26].

Compared to the high level of awareness found among cattle owners regarding the epidemiology of livestock diseases in the context of wildlife-livestock interface, the apparent 
absence of perception of zoonotic risks is striking. Although our survey was not designed to specifically evaluate the perception of disease risks for human health, the possible infection of humans was not mentioned, even for zoonotic diseases such as rabies, anthrax, brucellosis and (emerging) bovine tuberculosis. This may be linked to the poor development of public health facilities in these remote areas, which contrast with the relatively well developed and efficient veterinary extension services in the same areas. As suggested by Zinsstag et al. [4] for developing countries, this opportunity to enhance health awareness of people living in remote areas should be taken, adopting an integrated "One health" approach, taking advantage of the existing functional veterinary extension network.

Cattle keepers living at the periphery of conservation areas in the GL-TFCA and the KAZA-TFCA in Zimbabwe generally have a good knowledge base about livestock diseases and the epidemiological role played by wildlife. However, priority diseases perceived by cattle keepers vary greatly between sites, and independently of local abundance of wildlife. There is a need to involve cattle owners in decision-making processes regarding priorities for disease control, which may be achieved by adopting participatory epidemiology methods. Comparatively, awareness of zoonotic risks seemed poor among cattle owners, and the network and infrastructures for delivery of public health service were less developed than the veterinary services. Taking advantage of the existing agricultural and veterinary extension network, the implementation of a "One health" program to improve awareness and control of diseases would benefit public and veterinary health, and it could contribute to maintain a positive attitude of local communities towards wildlife and TFCAs initiatives. 


\section{Acknowledgements}

This work has been possible thanks to a trustful collaboration between research (University of Zimbabwe and Cirad) and Zimbabwe technical institutions, particularly the field services of the Governmental Veterinary Services. We would like to warmly thank GVS staff from Chiredzi and Hwange Districts for their collaboration, especially the Livestock and Veterinary Technicians who played an active role in the implementation of the questionnaire survey. This work was conducted within the framework of the Research Platform "Production and Conservation in Partnership" (RP-PCP) and the Animal and Human Health Environment and Development initiative (AHEAD). The project was funded by the European Union (PARSEL project) and by the Ministère Français des Affaires Etrangères through the French Embassy in Zimbabwe (RP-PCP grant 2008 \& 2009).

\section{Conflict of interest statement}

No financial and personal relationships with other people or organizations have inappropriately influenced this work.

\section{Role of the funding source}

Both funding source (European Commission through he PARSEL project and the Ministère Français des Affaires Etrangères through the French Embassy in Zimbabwe (RP-PCP grant 2008 \& 2009) were not involved in the protocol design, analysis and interpretation of the data.

\section{References}

[1] du Toit JT. Coexisting with cattle. Science. 2011;33:1710-1. 
[2] Lamarque F, Anderson J, Fregusson R, Lagrange M, Osei-Owusu Y, Bakker L. Humanwildlife conflict. causes, consequences and management strategies. Rome: FAO; 2009.

[3] de Garine-Wichatitsky M, Fritz H, Chaminuka P, Caron A, Guerbois C, Pfukenyi DM, et al. Consequences of animals crossing the edges of transfrontier parks. In: Andersson JA, de Garine-Wichatitsky M, Cumming DHM, Dzingirai V, Giller KE, editors. Transfrontier Conservation Areas People Living on the Edge. New York and London: Earthscan; In press.

[4] Zinsstag J, Schelling E, Wyss K, Mahamat MB. Potential of cooperation between human and animal health to strengthen health systems. Lancet. 2005;366:2142-45.

[5] Daszak P, Cunningham AA, Hyatt AD. Emerging infectious diseases of wildlife-threats to biodiversity and human health. Science. 2000;287:443-9.

[6] Yang D, Dai X, Deng Y, Lu W, Jiang Z. Changes in attitudes toward wildlife and wildlife meats in Human Province, central China, before and after the severe acute respiratory syndrome outbreak. Integrative Zoology. 2007;1:19-25.

[7] Weber TP, Stilianakis NI. Ecologic Immunology of Avian Influenza (H5N1) in Migratory Birds. Emerging Infectious Diseases. 2007;13:1139-43.

[8] Jones KE, Patel NG, Levy MA, Storeygard A, Balk D, Gittleman JL, et al. Global trends in emerging infectious diseases. Nature. 2008;451:990-4.

[9] OIE. Terrestrial Animal Health Code. 20th edition ed. Paris, France2011.

[10] Thomson GR, Vosloo W, Bastos ADR. Foot-and-mouth disease in wildlife. Virus Research. 2003;91:145-61. 
[11] Vosloo W, Boshoff K, Dwarka R, Bastos A. The possible role that buffalo played in the recent outbreaks of foot-and-mouth disease in South Africa. Ann N Y Acad Sci.

2002;969:187-90.

[12] Osofsky SA, Cleaveland S, Karesh WB, Kock MD, Nyhus PJ, Starr L, et al.

Conservation and development interventions at the wildlife/livestock interface: implications for wildlife, livestock and human health. In: IUCN, editor. Gland, Switzerland2005. p. xxxiii +220 pp.

[13] Bengis RG. Transfrontier Conservation Area Initiatives in Sub-Saharan Africa: Some Animal Health Challenges. In: Osofsky SA, Cleaveland S, Karesh WB, Kock MD, Nyhus PJ, Starr L, et al., editors. Conservation and development interventions at the wildlife/livestock interface: implications for wildlife, livestock and human health. Gland, Switzerland: IUCN; 2005. p. 15-9.

[14] Caron A, Miguel E, Gomo C, Makaya P, Pfukenyi D, Hove T, et al. Infection burden of ungulate populations living at the wildlife/livestock interface within the Great Limpopo Transfrontier Conservation Area in Zimbabwe. Submitted.

[15] Grahn R, Leyland T. Complementarity between Community-Based animal Health Delivery systems and Community-Based Wildlife Management? An analysis of experiences linking animal helath to conflict mangement in pastoralist areas of the horn of Africa. In: Osofsky SA, Cleaveland S, Karesh WB, Kock MD, Nyhus PJ, Starr L, et al., editors. Conservation and development interventions at the wildlife/livestock interface: implications for wildlife, livestock and human health. Gland, Switzerland: IUCN; 2005. p. 133-9.

[16] Catley A, Alders R, Wood J. Participatory epidemiology: Approaches, methods, experiences. The Veterinary Journal. 2012;191:151-60. 
[17] Munyeme M, Muma JB, Munan'andu H, Kankya C, Skjerve E, Tryland M. Cattle owner's awareness of bovine tuberculosis in high and low prevalence settings of the livestockwildlife interface areas in Zambia. BMC veterinary research. 2010;6:doi:10.1186/746-6148-621.

[18] Brook RK, McLachlan SM. Factors influencing farmers' concerns regarding bovine tuberculosis in wildlife and livestock around Riding Mountain National Park. Journal of environmental management. 2006;80:156-66.

[19] Bellan S, Pulliam J, Scott J, Dushoff J, Committee MO. How to Make Epidemiological Training Infectious. PLoS Biol. 2012;10:e1001295.

[20] Siembieda JL, Kock RA, McCracken TA, Newman SH. The role of wildlife in transboundary animal diseases. Animal Health Research Reviews. 2011:1-17.

[21] Mukamuri B, Chirozva C, Matema C, Matema S, Twine W, Nzuma T. Ethnic heterogeneity and its implications for natural resources management on the Edge. In: Andersson JA, de Garine-Wichatitsky M, Cumming DHM, Dzingirai V, Giller KE, editors. Transfrontier Conservation Areas People Living on the Edge. New York and London: Earthscan; In press.

[22] Wittemyer G, Elsen P, Bean WT, Burton ACO, Brashares JS. Accelerated human population growth at protected area edges. Science. 2008;321.

[23] Joppa L, Loarie S, Pimm S. On population growth near protected areas. PLoS ONE. 2009;4:ppe4279.

[24] Weiss M. Cultural epidemiology: an introduction and overview. Anthropology \& Medicine. 2001;8:5-29. 
[25] R Development Core Team. R: A language and Environment for Statistical Computing. In: Computing RFfS, editor. Vienna, Austria: R Foundation for Statistical Computing; 2011. [26] de Garine-Wichatitsky M, Caron A, Gomo A, Foggin C, Dutlow K, Pfukenyi D, et al. Bovine tuberculosis in Buffaloes, Southern Africa. Emerging Infectious Diseases. 2010;16:884-5.

[27] Gomo C, de Garine-Wichatitsky M, Caron A, Pfukenyi DM. Survey of brucellosis at the wildlife-livestock interface on the Zimbabwean side of the Great Limpopo Transfrontier Conservation Area. Trop Anim Health Prod. 2012;44:77-85.

[28] Foggin C. Zimbabwe's livestock disease control policy in relation to fencing. In:

Ferguson K, Hanks J, editors. A review of the environmental, social and economic impacts of game an veterinary fencing in Africa with particular reference to the Great Limpopo and Kavango-Zambezi Transfrontier Conservation Areas. Pretoria: Mammal Research Institute; 2010. p. $75-82$.

[29] Kock R. What is this Infamous "Wildlife/livestock Interface?" A Review of Current Knowledge. In: Ososfsky S, Cleaveland S, Karesh WB, Kock MD, Nyphus PJ, Starr L, et al., editors. Conservation and Development Interventions at the Wildlife/Livestock Interface: Implications for Wildlife, Livestock and Human Health. Gland, Switzerland, Cambridge, UK: IUCN; 2005. p. xxxiii+220.

[30] Munyeme M, Muma JB, Samui KL, Skjerve E, Nambota AM, Phiri IG, et al. Prevalence of bovine tuberculosis and animal level risk factors for indigenous cattle under different grazing strategies in the livestock/wildlife interface areas of Zambia. Trop Anim Health Prod. 2008. 
[31] Michel AL, Bengis RG, Keet DF, Hofmeyr M, de Klerk LM, Cross PC, et al. Wildlife tuberculosis in South African conservation areas: Implications and challenges. Veterinary microbiology. 2006;112:91-100. 


\section{Figure Caption}

Figure 1: Location of survey sites in Southern Africa (a) and Zimbabwe (b). Dip-tanks (black dots) visited in the KAZA-TFCA (c) and the GL-TFCA (d)

\section{Table Captions}

Table 1: Names of livestock diseases most frequently mentioned by cattle keepers $(n=254)$ in Zimbabwe. Only names mentioned by more than 5 respondents are shown in this table. Frequency (Freq.) and average rank (Av. rank) calculated for all respondents; Rank and \% of responses for each ethno-linguisitc group considered.

Table 2: Ranking of livestock diseases/syndromes by cattle owners $(n=254)$ in Zimbabwe Transfrontier Conservation areas. Most frequently cited diseases/dyndromes (Overall mean \% of citations), mean rank and standard error (SE_Rank) calculated over 12 groups of dip-tanks (DT\#1=Chanienga, DT\#2=Chikhovo/Makambe, DT\#3=Chomupani// Gurungweni/Pfumare, DT\#4=Faversham/Nyabongwe/Nyangambe, DT\#5=Chizvirizvi, DT\#6=Davata/Maose, DT\#7Piri/Tsovani; DT\#8=Chezhou/ Mabale/Sialwindi; DT\#9= Malipati/Muhlekwani, DT\#10=Pahlela, DT\#11=Pesvi; DT\#12=Chikombedzi/Chigweziwa).

Table 3: Most frequently cited $(n>=7)$ livestock diseases by cattle owners in Zimbabwe ( $n=1050$ citations). Perceived involvement of wildlife: "Don't know", "No" and "Yes" refers to farmers'reply to the question "Is this disease related to wildlife?" (NA=Not available); Grey cells represent expert knowledge most probable answer to this question. "Species citation" refers to the number of time a wildlife species has been cited for a role in the disease and most cited wildlife species (percentage of "wildlife citation"). 
Table 4: Agreement of farmers' answers with common veterinary knowledge about the role of wildlife in the disease epidemiology for the most cited diseases $(n>7)$. 


\begin{tabular}{|c|c|c|c|c|c|c|c|c|c|c|c|}
\hline Vernacular Name & Disease/Syndrome & \multicolumn{2}{|c|}{$\begin{array}{l}\text { All respondents } \\
(n=254)\end{array}$} & \multicolumn{2}{|c|}{ Ndebele (n=31) } & \multicolumn{2}{|c|}{ Shona $(n=69)$} & \multicolumn{2}{|c|}{ Shangani (n=135) } & \multicolumn{2}{|c|}{$\begin{array}{l}\text { Other minorities } \\
(n=11)\end{array}$} \\
\hline Foot_and_Mouth & Foot and mouth & 153 & 2.451 & 1 & $64.52 \%$ & 1 & $52.17 \%$ & 1 & $62.96 \%$ & 1 & $54.55 \%$ \\
\hline Heartwater & Heartwater & 76 & 3.750 & 2 & $48.39 \%$ & 3 & $28.99 \%$ & 3 & $27.41 \%$ & & $0.00 \%$ \\
\hline Lumpy_Skin & Lumpy Skin & 67 & 3.896 & 4 & $25.81 \%$ & 5 & $20.29 \%$ & 3 & $27.41 \%$ & 2 & $36.36 \%$ \\
\hline Anthrax & Anthrax & 50 & 1.260 & 7 & $9.68 \%$ & 6 & $18.84 \%$ & 4 & $19.26 \%$ & 3 & $27.27 \%$ \\
\hline Chamahwanda & Foot and mouth & 25 & 2.200 & 9 & $3.23 \%$ & 7 & $17.39 \%$ & 8 & $8.15 \%$ & & $0.00 \%$ \\
\hline Gall_sickness & Anaplasmosis & 24 & 1.000 & 5 & $22.58 \%$ & 10 & $7.25 \%$ & 9 & $7.41 \%$ & & $0.00 \%$ \\
\hline Chipfau & Blackleg & 23 & 1.652 & & $0.00 \%$ & 7 & $17.39 \%$ & 8 & $8.15 \%$ & & $0.00 \%$ \\
\hline Lumpskin & Lumpy Skin & 22 & 3.591 & 7 & $9.68 \%$ & 10 & $7.25 \%$ & 7 & $9.63 \%$ & & $0.00 \%$ \\
\hline Rabies & Rabies & 22 & 6.955 & 8 & $6.45 \%$ & 9 & $8.70 \%$ & 7 & $9.63 \%$ & & $0.00 \%$ \\
\hline Kusvodza & Brucellosis & 13 & 2.385 & 9 & $3.23 \%$ & 9 & $8.70 \%$ & 13 & $4.44 \%$ & & $0.00 \%$ \\
\hline Nyongo & Anaplasmosis & 12 & 1.000 & 7 & $9.68 \%$ & 13 & $2.90 \%$ & 13 & $4.44 \%$ & 5 & $9.09 \%$ \\
\hline Chimee & Heartwater & 11 & 3.636 & 9 & $3.23 \%$ & 12 & $4.35 \%$ & 12 & $5.19 \%$ & & $0.00 \%$ \\
\hline Quarter_evil & Blackleg & 9 & 1.444 & & $0.00 \%$ & 13 & $2.90 \%$ & 13 & $4.44 \%$ & 5 & $9.09 \%$ \\
\hline Isikwekwe & Dermatophilosis & 8 & 1.375 & 6 & $19.35 \%$ & & $0.00 \%$ & & $0.00 \%$ & 4 & $18.18 \%$ \\
\hline Newcastle & Newcastle & 8 & 5.625 & 8 & $6.45 \%$ & 14 & $1.45 \%$ & 15 & $2.96 \%$ & & $0.00 \%$ \\
\hline Tungundu & Anthrax & 8 & 1.125 & 9 & $3.23 \%$ & 11 & $5.80 \%$ & 16 & $2.22 \%$ & & $0.00 \%$ \\
\hline Chigwadara & Anthrax & 7 & 1.143 & 9 & $3.23 \%$ & 14 & $1.45 \%$ & 14 & $3.70 \%$ & & $0.00 \%$ \\
\hline Chikwekwe & Ticks & 7 & 5.714 & 9 & $3.23 \%$ & 13 & $2.90 \%$ & 16 & $2.22 \%$ & 5 & $9.09 \%$ \\
\hline Opthlamia & Contagious Opthalmia & 7 & 2.286 & 9 & $3.23 \%$ & & $0.00 \%$ & 16 & $2.22 \%$ & 5 & $9.09 \%$ \\
\hline Contagious_abortion & Brucellosis & 6 & 2.833 & & $0.00 \%$ & & $0.00 \%$ & 14 & $3.70 \%$ & & $0.00 \%$ \\
\hline Scours & Scours & 6 & 6.333 & 9 & $3.23 \%$ & & $0.00 \%$ & 16 & $2.22 \%$ & & $0.00 \%$ \\
\hline
\end{tabular}




\begin{tabular}{|c|c|c|c|c|c|c|c|c|c|c|c|c|c|c|c|}
\hline Disease & Mean \% & Mean Rank & SE_Rank & DT\#1 & DT\#2 & DT\#3 & DT\#4 & DT\#5 & DT\#6 & DT\#7 & DT\#8 & DT\#9 & DT\#10 & DT\#11 & DT\#12 \\
\hline Foot and mouth & 0.78 & 1.17 & 0.30 & 1 & 1 & 2 & 1 & 2 & 1 & 1 & 1 & 1 & 1 & 1 & 1 \\
\hline Lumpy skin & 0.50 & 2.67 & 0.74 & 2 & 2 & 3 & 2 & 3 & 2 & 3 & 4 & 2 & 5 & 2 & 3 \\
\hline Blackleg & 0.49 & 3.00 & 0.84 & 1 & 3 & 4 & 3 & 1 & 3 & 2 & 5 & 4 & 2 & 3 & 4 \\
\hline Heartwater & 0.35 & 4.08 & 0.78 & 4 & 2 & 5 & 5 & 6 & 4 & 4 & 4 & 3 & 5 & 4 & 4 \\
\hline Anthrax & 0.29 & 4.75 & 1.02 & 2 & 4 & 7 & 4 & 5 & 5 & 3 & 7 & 6 & 5 & 5 & 3 \\
\hline Babesiosis & 0.24 & 5.92 & 2.28 & 6 & 9 & 11 & 4 & 4 & 7 & 3 & 9 & 7 & 6 & 6 & 1 \\
\hline NID Limping & 0.16 & 6.67 & 2.63 & & 6 & 11 & 6 & 9 & 7 & & & 11 & 3 & & 2 \\
\hline Anaplasmosis & 0.15 & 6.33 & 2.13 & 7 & 7 & 11 & 10 & & 5 & & 6 & 5 & 3 & 5 & \\
\hline Rabies & 0.15 & 6.29 & 1.33 & 3 & 5 & 5 & 8 & 7 & & & & 9 & 6 & & \\
\hline Brucellosis & 0.10 & 6.86 & 1.06 & 7 & 7 & 9 & 7 & 8 & & & & 7 & 6 & & 4 \\
\hline NID Neurological & 0.08 & 6.57 & 2.00 & & 8 & 8 & 10 & & 6 & 5 & & & & & 3 \\
\hline Foot Rot & 0.08 & 7.45 & 2.10 & 4 & 8 & 11 & 9 & 6 & 7 & 5 & 9 & 12 & 6 & & 4 \\
\hline Mastitis & 0.07 & 6.00 & 2.40 & 7 & & & & 4 & 7 & & & 11 & 4 & 4 & \\
\hline NID Ocular & 0.06 & 7.86 & 1.83 & 7 & & & 10 & 6 & 7 & & 9 & 11 & 6 & & \\
\hline Ticks & 0.04 & 8.14 & 1.67 & 7 & 9 & 10 & 10 & 10 & & & 6 & & 6 & & \\
\hline NID Digestive & 0.04 & 7.40 & 1.88 & 5 & 9 & 10 & & 8 & & & & & & & 4 \\
\hline NID Diarrhoea & 0.04 & 8.29 & 2.00 & 7 & 9 & 12 & & 7 & & & 9 & 12 & 5 & & \\
\hline NID Cutaneous & 0.04 & 8.67 & 0.72 & & & 10 & 10 & 9 & & & 8 & 10 & & & \\
\hline Newcastle & 0.04 & 8.20 & 1.76 & 7 & 9 & & & 10 & 7 & 5 & & 10 & & & \\
\hline NID Respiratory and death & 0.03 & 7.25 & 1.75 & & 9 & & 9 & & 7 & & & & & & 4 \\
\hline NID Paralysis & 0.03 & 8.17 & 1.36 & 7 & 8 & & & 8 & 7 & & 8 & 12 & & & \\
\hline NID Salivation & 0.03 & 9.20 & 1.04 & & 9 & 11 & 10 & 9 & 7 & & & & & & \\
\hline Dermatophilosis & 0.03 & 4.50 & 0.00 & & & & & & & & 3 & & & & \\
\hline Theileriosis & 0.01 & 7.80 & 2.25 & & & & & 10 & 7 & & & 12 & & 6 & \\
\hline
\end{tabular}




\begin{tabular}{|c|c|c|c|c|c|c|c|}
\hline Disease or syndrom & $\begin{array}{r}\begin{array}{r}\text { Citation } \\
(\mathbf{n})\end{array} \\
\end{array}$ & $\begin{array}{l}\text { Don't } \\
\text { know }\end{array}$ & No & Yes & $\begin{array}{l}\text { Species } \\
\text { Citation }\end{array}$ & Main wildlife species cited & Second most cited wildilfe species \\
\hline Foot and mouth & 190 & $18 \%$ & $4 \%$ & $77 \%$ & 171 & Buffalo (82\%) & Wildebeest (6\%) \\
\hline Lumpy skin & 127 & $52 \%$ & $26 \%$ & $22 \%$ & 35 & Buffalo (54\%) & Wildebeest (17\%) \\
\hline Blackleg & 122 & $39 \%$ & $29 \%$ & $32 \%$ & 50 & Buffalo $(62 \%)$ & Wildebeest (14\%) \\
\hline Heartwater & 89 & $39 \%$ & $37 \%$ & $24 \%$ & 26 & Buffalo (62\%) & Wildebeest (11.5\%) \\
\hline Anthrax & 67 & $46 \%$ & $22 \%$ & $31 \%$ & 34 & Buffalo (47\%) & Wildebeest (15\%) \\
\hline Babesiosis & 43 & $33 \%$ & $47 \%$ & $21 \%$ & 10 & Buffalo $(80 \%)$ & Eland (10\%), Elephant (10\%) \\
\hline Anaplasmosis & 42 & $38 \%$ & $33 \%$ & $29 \%$ & 14 & Buffalo (57\%) & Elephant $(14 \%)$ \\
\hline NID & 42 & $48 \%$ & $24 \%$ & $29 \%$ & 14 & Buffalo (64\%) & Greater kudu (14\%), Wildebeest (14\%) \\
\hline Rabies & 38 & $8 \%$ & $0 \%$ & $92 \%$ & 41 & Jackal $(78 \%)$ & Wild $\operatorname{dog}(12 \%)$ \\
\hline NID Limping & 28 & $46 \%$ & $32 \%$ & $21 \%$ & 6 & Buffalo $(67 \%)$ & Eland (17\%), Elephant (17\%) \\
\hline Brucellosis & 23 & $39 \%$ & $48 \%$ & $13 \%$ & 4 & Buffalo $(50 \%)$ & $\begin{array}{l}\text { Greater kudu (25\%), All wild animals } \\
(25 \%)\end{array}$ \\
\hline Foot Rot & 19 & $42 \%$ & $37 \%$ & $21 \%$ & 4 & Buffalo (75\%) & All antelopes $(25 \%)$ \\
\hline Mastitis & 17 & $53 \%$ & $35 \%$ & $12 \%$ & 5 & Buffalo $(40 \%)$ & Sable $(20 \%)$ \\
\hline NID Ocular & 16 & $44 \%$ & $44 \%$ & $13 \%$ & 3 & Buffalo (67\%) & Elephant $(33 \%)$ \\
\hline NID Neurological & 15 & $40 \%$ & $53 \%$ & $7 \%$ & 0 & NA & NA \\
\hline NID Cutaneous & 14 & $50 \%$ & $29 \%$ & $21 \%$ & 4 & Bushpig (50\%), Wildebeest (50\%) & NA \\
\hline NID Diarrhoea & 14 & $57 \%$ & $29 \%$ & $14 \%$ & 2 & Buffalo $(100 \%)$ & NA \\
\hline Ticks & 13 & $46 \%$ & $0 \%$ & $54 \%$ & 9 & Wildebeest (33\%) & Bushpig (22\%) \\
\hline Dermatophilosis & 10 & $40 \%$ & $20 \%$ & $40 \%$ & 4 & Buffalo (50\%) & Bushpig (25\%), Wildebeest (25\%) \\
\hline NID Digestive & 10 & $50 \%$ & $30 \%$ & $20 \%$ & 1 & Buffalo $(100 \%)$ & NA \\
\hline NID Paralysis & 10 & $40 \%$ & $0 \%$ & $60 \%$ & 7 & Buffalo $(71 \%)$ & Impala (14\%), Warthog (14\%) \\
\hline Newcastle & 8 & $63 \%$ & $25 \%$ & $13 \%$ & 1 & Buffalo $(100 \%)$ & NA \\
\hline Contagious Opthalmia & 7 & $14 \%$ & $57 \%$ & $29 \%$ & 2 & Buffalo $(100 \%)$ & NA \\
\hline NID Salivation & 7 & $57 \%$ & $43 \%$ & $0 \%$ & 0 & NA & NA \\
\hline Theileriosis & 7 & $57 \%$ & $0 \%$ & $43 \%$ & 5 & Buffalo $(60 \%)$ & Wildebeest (25\%), Elephant (25\%) \\
\hline
\end{tabular}




\begin{tabular}{|c|c|c|c|}
\hline \multirow{2}{*}{$\begin{array}{l}\text { Disease } \\
\text { Name }\end{array}$} & \multirow[b]{2}{*}{ Citation } & \multicolumn{2}{|c|}{ Agreement with veterinary knowledge } \\
\hline & & $n$ & $\%$ \\
\hline Foot and mouth & 190 & 147 & $77,4 \%$ \\
\hline Lumpy Skin & 127 & 28 & $22,0 \%$ \\
\hline Blackleg & 122 & 42 & $34,4 \%$ \\
\hline Heartwater & 89 & 21 & $23,6 \%$ \\
\hline Anthrax & 67 & 21 & $31,3 \%$ \\
\hline Babesiosis & 43 & 9 & $20,9 \%$ \\
\hline Anaplasmosis & 42 & 12 & $28,6 \%$ \\
\hline Rabies & 38 & 35 & $92,1 \%$ \\
\hline Brucellosis & 23 & 3 & $13,0 \%$ \\
\hline Foot Rot & 19 & 11 & $57,9 \%$ \\
\hline Mastitis & 17 & 7 & $41,2 \%$ \\
\hline Ticks & 13 & 7 & $53,8 \%$ \\
\hline Dermatophilosis & 10 & 4 & $40,0 \%$ \\
\hline Newcastle & 8 & 1 & $12,5 \%$ \\
\hline Contagious Opthalmia & 7 & 4 & $57,1 \%$ \\
\hline Theileriosis & 7 & 3 & $42,9 \%$ \\
\hline
\end{tabular}




\begin{tabular}{|c|c|c|}
\hline $\begin{array}{l}\text { Vernacular names given by } \\
\text { cattle owners during free-list }\end{array}$ & $\begin{array}{l}\mathrm{Nb} \\
\text { citations }\end{array}$ & $\begin{array}{l}\text { Most often associated scientific disease/syndrom } \\
\text { name (NID = Not Identified) }\end{array}$ \\
\hline Shona & 280 & \\
\hline Chahwandawo muromo & 1 & NID Digestive ('Mouth Dry')/Foot-and-Mouth disease \\
\hline Chamahwanda & 27 & Foot and mouth \\
\hline Chamapundu & 32 & Lumpy Skin \\
\hline Chamaziso & 2 & NID Ocular \\
\hline Chebandauko & 18 & NID Limping \\
\hline Chedzungu & 2 & NID Neurological \\
\hline Chekuoma chipfuva & 1 & NID ('Dry chest') \\
\hline Chekuomesa makumbo & 1 & Blackleg \\
\hline Chekutsemukahwanda & 1 & Foot Rot \\
\hline Chekuzeya & 1 & NID Neurological \\
\hline Chemanyoka & 1 & NID Diarrhoea \\
\hline Chemaziso & 1 & NID Ocular \\
\hline Chemureza & 1 & Foot and mouth \\
\hline Chenduru & 2 & Anaplasmosis \\
\hline Chenyeng'o & 2 & NID \\
\hline Cherurindi & 1 & NID Paralysis \\
\hline Cheshanga & 1 & NID Ocular \\
\hline Cheweti tsvuku & 2 & Babesiosis ('Red urine') \\
\hline Chibububu & 5 & NID respiratory and death \\
\hline Chigwadara & 7 & Anthrax \\
\hline Chikosoro & 1 & NID Respiratory \\
\hline Chikwekwe & 7 & Ticks \\
\hline Chimbwa mupengo & 15 & Rabies \\
\hline Chimee & 11 & Heartwater \\
\hline Chimeme & 2 & NID \\
\hline Chinzuwenzunzuwe & 1 & NID Neurological \\
\hline Chiomasusu & 1 & NID Digestive \\
\hline Chiomesa susuvarisa & 1 & NID Digestive ('Dry stomach') \\
\hline Chipfau & 25 & Blackleg \\
\hline Chirendelekani & 1 & NID Neurological \\
\hline Chirwere & 10 & NID ('Disease' generic term) \\
\hline Chizeezee & 2 & NID Neurological \\
\hline Chokudzadzarika & 1 & NID Neurological \\
\hline Chokuonda & 6 & NID Lose condition \\
\hline Chomunyaviri & 1 & NID \\
\hline Dzungu & 1 & NID \\
\hline Gomarara & 1 & NID/Cancer? \\
\hline Gwembe & 1 & NID Cutaneous \\
\hline Hwanda & 1 & NID/Foot-and-Mouth disease \\
\hline $\begin{array}{l}\text { Kubamuka mahwanda } \\
\text { nemuromo }\end{array}$ & 1 & NID Salivation/Foot-and-Mouth disease \\
\hline Kubhubhabhubha & 1 & NID \\
\hline Kubva & 2 & NID \\
\hline
\end{tabular}




\begin{tabular}{|c|c|c|}
\hline Kudhakwa & 1 & NID Neurological \\
\hline Kufa & 3 & NID/Sudden death ('Death') \\
\hline Kuhudha & 3 & NID Diarrhoea \\
\hline Kukamina & 2 & NID Limping \\
\hline Kukosora & 2 & NID Respiratory \\
\hline kuoma gumbo rimwe chete & 1 & NID Neurological \\
\hline Kuoma mutsipa & 1 & NID Neurological \\
\hline Kuomarara kwebandauko & 2 & Blackleg \\
\hline kuomesa shaya & 1 & NID Paralysis \\
\hline Kuora chiropa nerwatata & 1 & NID ('Rotten liver') \\
\hline Kuora hwanda & 1 & Foot Rot \\
\hline Kusvodza & 12 & Brucellosis \\
\hline Kusvuvuka mahwanda & 1 & Foot-and-Mouth disease ('Peeling of hooves') \\
\hline Kuunduka kwembudzi & 1 & NID \\
\hline Uwondoroka kwembudzi & 1 & NID \\
\hline Kuzvimba & 5 & NID (Lumps?) \\
\hline Makangazha & 1 & NID Limping \\
\hline Makanzo & 1 & NID Paralysis \\
\hline Manyoka emhuru & 1 & NID Diarrhoea \\
\hline Mapundu ehuku & 1 & Lumpy Skin \\
\hline Maronda pahuro & 1 & NID Salivation \\
\hline Masiriri & 2 & NID Salivation/Foot and mouth \\
\hline Mazizo & 2 & NID Ocular \\
\hline Mota pazamu & 1 & Mastitis \\
\hline Moyo une mvura & 1 & Heartwater \\
\hline Mudumbu & 1 & NID Internal parasites \\
\hline Mureza & 1 & Foot and mouth \\
\hline Mutitinini & 2 & Anthrax \\
\hline Muzungu & 1 & NID \\
\hline Nyongo & 11 & Anaplasmosis \\
\hline Tungundu & 8 & Anthrax \\
\hline Weti & 2 & Babesiosis \\
\hline Yokukabiya & 1 & Blackleg \\
\hline Zvipusha & 1 & NID \\
\hline Zvisasa & 1 & NID Cutaneous (Ring worms?) \\
\hline Shangani & 27 & \\
\hline Chamabhunzu & 3 & Lumpy Skin \\
\hline Chamavoya & 1 & NID Digestive \\
\hline Chenomo nenenge & 1 & Foot-and-Mouth Disease \\
\hline Chihetsele & 1 & NID Neurological \\
\hline Chikokwani & 1 & NID Paralysis \\
\hline Chinziwanziwani & 1 & NID Neurological \\
\hline Chivavo chamulenga nemilomo & 1 & Foot-and-Mouth Disease \\
\hline Chivavo chomumbelo & 1 & Mastitis \\
\hline Chochuluka & 1 & NID Diarrhoea \\
\hline Chokukwita & 1 & NID \\
\hline
\end{tabular}




\begin{tabular}{|c|c|c|}
\hline Chuluka & 1 & NID Diarrhoea \\
\hline Iomile voya & 1 & NID Digestive \\
\hline Isifo somukono & 1 & NID \\
\hline Isiso samapundu & 1 & Lumpy Skin \\
\hline Isululuwani & 1 & NID Neurological \\
\hline Kufa & 1 & NID ('Death') \\
\hline kukwita & 1 & NID Paralysis \\
\hline Kusvodza & 1 & Brucellosis \\
\hline Kusvomoka foya & 1 & Foot and mouth \\
\hline Mahlu & 2 & NID Ocular \\
\hline Makwande Namilomo & 1 & Foot-and-Mouth Disease \\
\hline Masondo ekukwamuka & 1 & Foot-and-Mouth Disease \\
\hline Masondo na mulomo malonda & 1 & Foot-and-Mouth Disease \\
\hline Nyongwa & 1 & Anaplasmosis \\
\hline Ndebele & 24 & \\
\hline Amehlo abe mhlope & 1 & NID Ocular ('White eye') \\
\hline Isikwekwe & 8 & NID Cutaneous/Dermatophilosis \\
\hline Izafesane & 1 & NID/Limping \\
\hline Izilonda lonyeni & 1 & Foot and mouth \\
\hline Mkono & 1 & NID Limping \\
\hline Nyongo & 1 & Anaplasmosis \\
\hline Ukugiqa & 1 & Sweating sickness \\
\hline Ukusubuka uboya & 1 & NID Cutaneous \\
\hline Umkhanza & 2 & Ticks \\
\hline Umkhono & 5 & NID \\
\hline Umkhuhlane & 2 & NID ('Disease' generic term)/Heartwater? \\
\hline Nambya & 1 & \\
\hline Chagobo & 1 & NID Cutaneous \\
\hline English & 718 & \\
\hline Abcess & 2 & NID Abcess \\
\hline Abortion & 2 & NID Abortion \\
\hline Anaplasmosis & 2 & Anaplasmosis \\
\hline Anthrax & 50 & Anthrax \\
\hline Bird flu & 1 & Avian Influenza \\
\hline Blackleg & 85 & Blackleg \\
\hline Blood in faeces & 1 & NID Diarrhoea \\
\hline Bloody dung and sudden death & 1 & NID Diarrhoea \\
\hline Brucellosis & 3 & Brucellosis \\
\hline Coccidiosis & 4 & Coccidiosis \\
\hline Contagious abortion & 6 & Brucellosis \\
\hline Cornea opacity & 1 & NID Ocular \\
\hline Dermatophilosis & 1 & Dermatophilosis \\
\hline Diarrhoea & 4 & NID Diarrhoea \\
\hline Early deaths of goat kids & 1 & NID Sudden death \\
\hline Emaciation & 1 & Blood sucking flies \\
\hline Ephemeral fever & 3 & Ephemeral fever \\
\hline
\end{tabular}




\begin{tabular}{|c|c|c|}
\hline Eye problem & 4 & NID Ocular \\
\hline Foot and Mouth & 153 & Foot-and-Mouth Disease \\
\hline Foot Rot & 17 & Foot Rot \\
\hline Fowl pox & 2 & Fowl pox \\
\hline Gall sickness & 24 & Anaplasmosis \\
\hline Giving birth of early born calves & 1 & NID Abortion \\
\hline Goitee & 2 & NID Cutaneous \\
\hline Hair peeling off & 1 & NID Cutaneous \\
\hline Heartwater & 76 & Heartwater \\
\hline Internal parasites & 3 & NID Internal parasites \\
\hline January disease & 2 & Theileriosis \\
\hline Joint illness & 1 & NID Limping \\
\hline Limping & 4 & NID Limping \\
\hline Liverfluke & 5 & Liver fluke \\
\hline Lumpy Skin ("Lumpskin") & 90 & Lumpy Skin \\
\hline Mange & 3 & Mange \\
\hline Mastitis & 15 & Mastitis \\
\hline Mucus & 2 & NID \\
\hline NA & 13 & NID \\
\hline Nagana & 1 & Trypanosomosis \\
\hline Newcastle & 8 & Newcastle \\
\hline Not grazing & 1 & NID Digestive \\
\hline Opthlamia & 7 & Contagious Opthalmia \\
\hline Parafilaria & 3 & Parafilariosis \\
\hline Paralysis & 2 & NID Paralysis \\
\hline Pulpy kidney & 1 & Pulpy kidney \\
\hline Quarter evil & 9 & Blackleg \\
\hline Rabies & 22 & Rabies \\
\hline Redwater & 39 & Babesiosis \\
\hline $\begin{array}{l}\text { Removal of skin all over the } \\
\text { body }\end{array}$ & 1 & NID Cutaneous \\
\hline Retention of the placenta & 1 & Placenta retention \\
\hline Rinderpest & 1 & Rinderpest \\
\hline Ring worm & 1 & NID Internal parasites \\
\hline Salivation & 2 & NID Salivation \\
\hline Scab & 3 & NID Cutaneous \\
\hline Scours & 6 & Scours \\
\hline Screwworms & 1 & Screw worms \\
\hline Sleeping sickness & 2 & Trypanosomosis \\
\hline Stress & 1 & NID Cutaneous \\
\hline Sudden death of cattle & 1 & NID Sudden death \\
\hline Sudden death of goats & 1 & NID Sudden death \\
\hline Sweating sickness & 1 & Sweating sickness \\
\hline Swollen neck & 1 & NID \\
\hline Tetanos & 1 & Tetanos \\
\hline Theileriosis & 5 & Theileriosis \\
\hline
\end{tabular}




\begin{tabular}{|l|l|l|} 
Tick borne disease & 1 & NID Tick borne disease \\
Ticks & 3 & Ticks \\
Tsetse flies & 1 & Glossina spp \\
Wuberculosis & 2 & Tuberculosis \\
Water dung of goats & 1 & Warts \\
Worms & 1 & NID Diarrhoea \\
\hline
\end{tabular}




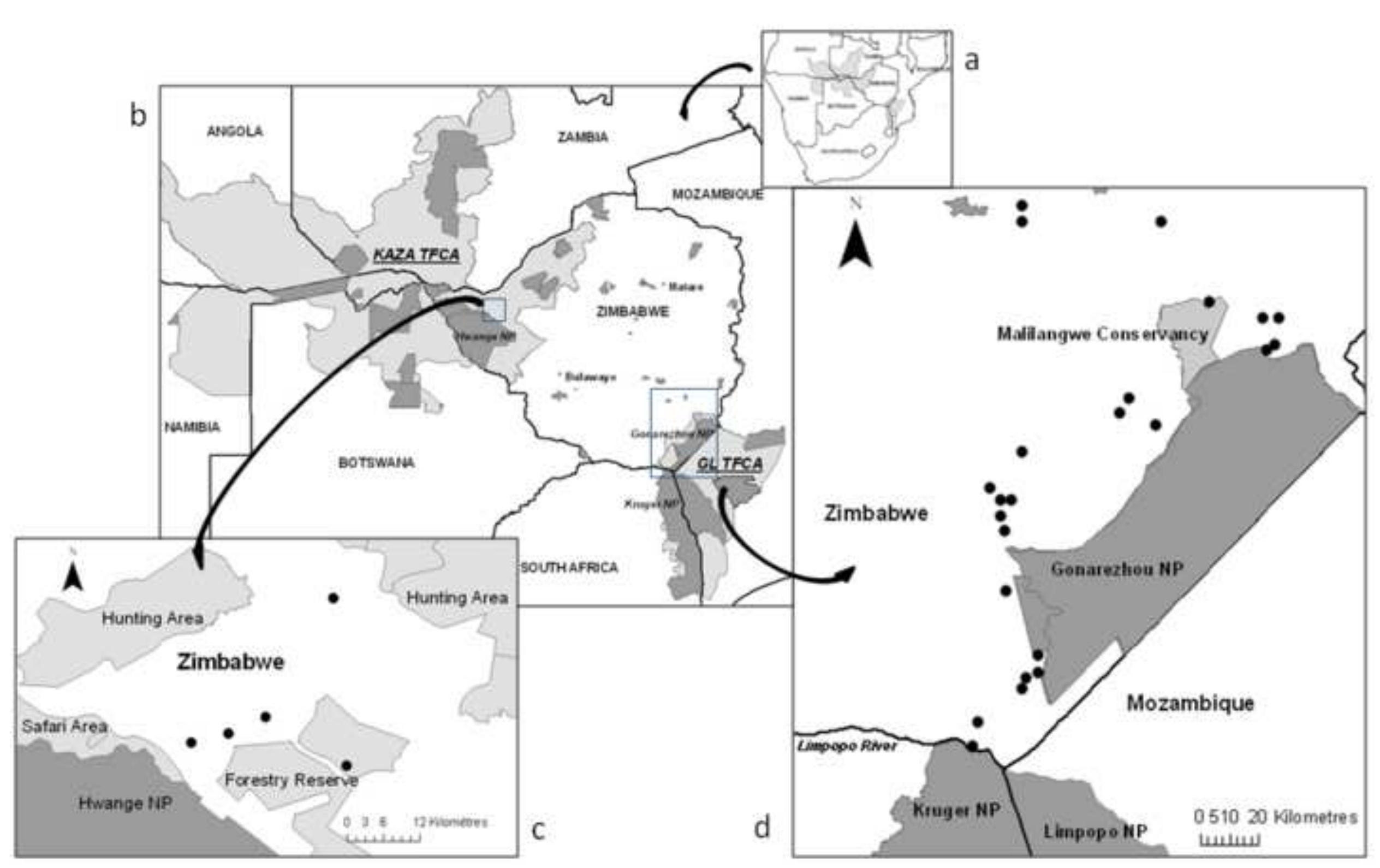

